\title{
Optimizing care and outcomes of patients with muscle-invasive bladder cancer
}

\author{
Christopher M. Booth, MD, FRCPC
}

Division of Cancer Care and Epidemiology, Queen's University Cancer Research Institute, Kingston, ON

Cite as: Can Urol Assoc J 2013;7(9-10):e625-7. http://dx.doi.org/10.5489/cuaj.1698

Published online October 9, 2013.

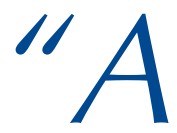
chieving the achievable" for patients with cancer requires that health providers and systems optimally use the best knowledge we already have. ${ }^{1}$ Fundamental questions that drive any quality improvement initiative include:

- Adoption: Are we treating the right patients? If not, why not?

- Quality of care: Are we treating patients the right way? If not, why not?

- Outcomes: Are we achieving the expected patient outcomes? (Effectiveness).

- If not, is the efficacy-effectiveness gap explained by sub-optimal adoption, quality of care and/or other factors? (Processes of Care)

Answers to these questions will identify remediable problems in the delivery of care, which in turn will inform future Knowledge Translation to improve the patient outcomes. ${ }^{2}$ The Canadian Association of Genitourinary Medical Oncologists (CAGMO) Consensus Statement regarding the use of neoadjuvant chemotherapy (NACT) for muscle-invasive bladder cancer (MIBC) is an important step towards improving the care of patients with this disease. ${ }^{3}$

\section{What does the current evidence tell us about optimal management of MIBC?}

Definitive management of MIBC involves cystectomy or radical radiotherapy (RT). There is a surprising lack of good comparative data evaluating whether one modality is superior to the other; it is, therefore, not surprising that variations in practice exist worldwide. This is reflected in the substantial discordance of international guidelines for the definitive management of MIBC; some guidelines strongly recommend cystectomy over RT, while other guidelines endorse both treatment options. ${ }^{4-8}$ The evidence and guidelines are much clearer for NACT. Efficacy of NACT has been clearly defined in a series of well-designed clinical trials and subsequent meta-analyses. ${ }^{9-13}$ The efficacy of adjuvant chemotherapy (ACT) is less clear, although the limited available evidence does suggest it might benefit patients with an effect size comparable to NACT. ${ }^{14-17}$ Based on this evidence, international guidelines recommend NACT for patients with MIBC, but do not endorse ACT. ${ }^{18-20}$

\section{What do we know about treatment in routine clinical practice?}

Unlike in some parts of Europe and Asia where RT is the preferred definitive treatment option for MIBC, North America has shown marked shifts in practice away from RT towards cystectomy. In many North American jurisdictions, the use of radical RT for MIBC is largely restricted to patients of advanced age and/or comorbidity. ${ }^{21-24}$ While differences in utilization of cystectomy or RT may be understood on the basis of a lack of comparative evidence, the use of perioperative chemotherapy in routine practice is not consistent with evidence of guidelines.

Multiple population-based reports in the United States $^{22,25,26}$ and Canada ${ }^{17,27}$ have reported dismally low rates of NACT utilization. Paradoxically, most studies report higher rates of ACT. This latter finding is particularly striking and suggests that patient and physician preferences need to be carefully considered in light of any program designed to improve the quality of care.

\section{CAGMO Consensus Statement}

On this background, Seah and colleagues should be congratulated for their thoughtful and comprehensive review of 
the evidence for NACT in MIBC and the streamlined process of care they propose. ${ }^{3}$ The consensus statement provides clear direction for practitioners regarding referral patterns, relevant investigations, timelines for care, and treatment recommendations. In addition to their careful review and well-constructed consensus statement, the CAGMO group also plans to study future NACT practices in Canada to see whether there is any improvement over time. It would have been helpful for the group to have done a baseline quantitative analysis of practice before publication and dissemination of the document. This would have allowed for a more insightful follow-up analysis. Despite this limitation, the authors have addressed an important issue and are making efforts to improve care in a very real way.

Further efforts are required to better understand the barriers to use of NACT. Although not the focus of their article, the potential underlying reasons for underutilization of NACT were discussed by Seah and colleagues. Patient preference and shared decision-making have not been well-described in MIBC. Findings from other studies suggest that there is considerable variability among patients regarding what factors influence their treatment preferences. ${ }^{28,29}$ Based on my own clinical experience, I believe that the absolute survival benefit of $5 \%$ is considered by many clinicians and patients to be modest in magnitude. The CAGMO authors believe the effect size of NACT for bladder cancer is comparable to the benefit of ACT for breast and colon cancer - on this point I would disagree. The relevant overviews in breast ${ }^{30}$ and colon cancer $^{31}$ suggest the effect size of ACT is slightly greater than $5 \%$ for all patients, and substantially greater than $5 \%$ among those patients with node positive disease. Future work is needed to understand how we might be able to use molecular tools to identify patients with MIBC who are likely to derive the greatest benefit from NACT. Indeed, treatment in the preoperative setting provides an ideal research model to identify biomarkers that could influence how we treat patients with this disease. ${ }^{32}$ Other aspects of quality care that require attention include the oft-forgotten role of curative intent RT for MIBC and the known association between cystectomy surgical volume and patient outcomes. ${ }^{33}$

While we wait for new treatments and molecular tools, we need to do a better job of using the best available knowledge to provide the best available treatment to our patients with MIBC. The consensus statement and the model of care proposed by Seah and colleagues is an important step in this direction.

Competing interests: None declared.

\section{References}

1. Mackillop WJ. Health Services Research in Radiation Oncology: Toward Achieving the Achievable. In: Gunderson LL, Tepper JE, editors. Clinical Radiation Oncology. Philadelphia: Churchill Livingstone;2007:215-37.

2. Donabedian A. Evaluating the quality of medical care. 1966. Milbank Q 2005;83:691-729. http:// dx.doi.org/10.1111/i.1468-0009.2005.00397.x

3. Seah J, Sridhar S, Blais N, et al. Neoadjuvant chemotherapy should be administered to fit patients with newly diagnosed, potentially resectbale muscle-invasive urothelial cancer of the bladder: a 2013 CAGMO consensus statement and call for a streamlined referral process. Can Urol Assoc J 2013;7:312-8. http:// dx.doi.org/10.5489/cuaj.1506

4. Malkowicz SB, van PH, Mickisch G, et al. Muscle-invasive urothelial carcinoma of the bladder. Urology 2007;69(1 Suppl):3-16. hitp://dx.doi.org/10.1016/i.urology.2006.10.040

5. Bellmunt J, Albiol S, Kataja V. Invasive bladder cancer: ESMO clinical recommendations for diagnosis, treatment and follow-up. Ann Oncol 2009;20(Suppl 4):79-80. http://dx.doi.org/10.1093/annonc/ $\mathrm{mdp} 136$

6. Stenzl A, Cowan NC, De SM, et al. Treatment of muscle-invasive and metastatic bladder cancer: update of the EAU guidelines. Eur Urol 2011;59:1009-18. http://dx.doi.org/10.1016/.eururo.2011.03.023

7. National Comprehensive Cancer Network. NCCN Guidelines Bladder Cancer; 2012. http://www.ncen. org/professionals/physician_gls/pdf/bladder.pdf. Accessed September 24, 2013.

8. Scottish Intercollegiate Guidelines Network. Management of transitional cell carcinoma of the bladder: a national clinical guideline. 2005. Edinburgh, Scotland, National Health Service. http://www.sign.ac.uk/ guidelines/fulltext/85/index.html. Accessed September 24, 2013.

9. Neoadjuvant cisplatin, methotrexate, and vinblastine chemotherapy for muscle-invasive bladder cancer: a randomised controlled trial. International collaboration of trialists. Lancet 1999;354:533-540. http:// dx.doi.org/10.1016/S0140-6736(99)02292-8

10. Griffiths $G$, Hall R, Sylvester R, et al. International phase III trial assessing neoadjuvant cisplatin, methotrexate, and vinblastine chemotherapy for muscle-invasive bladder cancer: long-term results of the BA06 30894 trial. J Clin Oncol 201 1;29:2171-7. http://dx.doi.org/10.1200/JC0.2010.32.3139

11. Grossman $H B$, Natale RB, Tangen $C M$, et al. Neoadjuvant chemotherapy plus cystectomy compared with cystectomy alone for locally advanced bladder cancer. N Engl J Med 2003;349:859-66. http://dx.doi. org/10.1056/NEJMoc022148

12. Winquist E, Kirchner TS, Segal R, et al. Neoadjuvant chemotherapy for transitional cell carcinoma of the bladder: a systematic review and meta-analysis. J Urol 2004;171 (2 Pt 1):561-9. http://dx.doi. org/10.1097/01.ju.0000090967.08622.33

13. Neoadjuvant chemotherapy in invasive bladder cancer: update of a systematic review and meta-analysis of individual patient data advanced bladder cancer (ABC) meta-analysis collaboration. Eur Urol 2005; 48(2):202-205. http://dx.doi.org/10.1016/i.eururo.2005.04.006

14. Adjuvant chemotherapy in invasive bladder cancer: a systematic review and meta-analysis of individual patient data Advanced Bladder Cancer (ABC) Meta-analysis Collaboration. Eur Urol 2005; 48(2):189-199. http://dx.doi.org/10.1016/j.eururo.2005.04.005

15. Ruggeri EM, Giannarelli D, Bria E, et al. Adjuvant chemotherapy in muscle-invasive bladder carcinoma: a pooled analysis from phase III studies. Cancer 2006;106:783-8. http://dx.doi.org/10.1002/ cncr.21676

16. Svatek RS, Shariat SF, Lasky RE, et al. The effectiveness of off-protocol adjuvant chemotherapy for patients with urothelial carcinoma of the urinary bladder. Clin Cancer Res 2010;16:4461-7. http:// dx.doi.org/10.1158/1078-0432.CCR-10-0457

17. Booth CM, Siemens DR, Li G, et al. Neoadjuvant (NACT) and adjuvant (ACT) chemotherapy for muscleinvasive bladder cancer: a population-based outcomes study. Ann Oncol 23 [9S]. 2012.

18. Winquist $E$, Waldron $T$, Segal $R$, et al. Use of neoadjuvant chemotherapy in transitional cell carcinoma of the bladder Practice Guideline Report \#3-2-2. Cancer Care Ontario Program in Evidence-Based Care. https://www.cancercare.on.ca/toolbox/qualityguidelines/diseasesite/genito-ebs/. Accessed September 24, 2013.

19. Sternberg CN, Donat SM, Bellmunt J, et al. Chemotherapy for bladder cancer: treatment guidelines for neoadjuvant chemotherapy, bladder preservation, adjuvant chemotherapy, and metastatic cancer. Urology 2007;69(1 Suppl):62-79. http://dx.doi.org/10.1016/i.urology.2006.10.041

20. Segal R, Winquist E, Lukka H, et al. Use of Adjuvant Chemotherapy Following Cystectomy in Patients with Deep Muscle-Invasive Transitional Cell Carcinoma of the Bladder Practice Guideline Report \#3-2-1. Cancer Care Ontario Program in Evidence-Based Care, editor. https://www.cancercare.on.ca/toolbox/ qualityguidelines/diseasesite/genito-ebs/. Accessed September 24, 2013.

21. Hayter $C R$, Paszat $L F$, Groome PA, et al. The management and outcome of bladder carcinoma in Ontario, 1982 1994. Cancer 2000;89:142-51. http://dx.doi.org/10.1002/1097-0142(20000701)89:1<142::AlDCNCR19>3.0.C0;2-4 
22. Schrag D, Mitra N, Xu F, et al. Cystectomy for muscle-invasive bladder cancer: patterns and outcomes of care in the Medicare population. Urology 2005;65:1118-25. http://dx.doi.org/10.1016/j.uroogy.2004.12.029

23. Snyder $C$, Harlan $L$, Knopf $K$, et al. Patterns of care for the treatment of bladder cancer. J Urol 2003;169:1697-701. http://dx.doi.org/10.1097/01.ju.0000056727.30546.b7

24. Gore JL, Litwin MS, Lai J, et al. Use of radical cystectomy for patients with invasive bladder cancer. J Natl Cancer Inst 2010; 102(11):802-811. http://dx.doi.org/10.1093/inci/diq121

25. David KA, Milowsky MI, Ritchey J, et al. Low incidence of perioperative chemotherapy for stage III bladder cancer 1998 to 2003: a report from the National Cancer Data Base. J Urol 2007;178:451-4. http:// dx.doi.org/10.1016/i.juro.2007.03.101

26. Porter MP, Kerrigan MC, Donato BMK, et al. Patterns of use of systemic chemotherapy for Medicare beneficiaries with urothelial bladder cancer. Urol Oncol 201 1;29:252-8. http://dx.doi.org/10.1016/i. urolonc.2009.03.021

27. Yafi FA, Aprikian AG, Chin JL, et al. Contemporary outcomes of 2287 patients with bladder cancer who were treated with radical cystectomy: a Canadian multicentre experience. BJU Int 2011;108:539-45. http://dx.doi.org/10.1111/j.1464-410X.2010.09912.x

28. Feldman-Stewart $D$, Brundage MD, Van ML, et al. Patient-focussed decision-making in early-stage prostate cancer: insights from a cognitively based decision aid. Health Expect 2004;7:126-41. http://dx.doi. org/10.1111/i.1369-7625.2004.00271.x
29. Sheridan SL, Felix K, Pignone MP, et al. Information needs of men regarding prostate cancer screening and the effect of a brief decision aid. Patient Educ Couns 2004;54:345-51. http://dx.doi.org/10.1016/i. pec.2003.12.003

30. Polychemotherapy for early breast cancer: an overview of the randomised trials. Early Breast Cancer Trialists' Collaborative Group. Lancet 1998;352:930-42. http://dx.doi.org/10.1016/S01406736(98)03301-7

31. Gill S, Loprinzi CL, Sargent DJ, et al. Pooled analysis of fluorouracil-based adjuvant therapy for stage II and III colon cancer: who benefits and by how much? I Clin Oncol 2004;22:1797-806. http://dx.doi. org/10.1200/JC0.2004.09.059

32. Chism DD, Woods ME, Milowsky MI. Neoadjuvant paradigm for accelerated drug development: an ideal model in bladder cancer. Oncologist 2013;18:933-40. http://dx.doi.org/10.1634/theoncologist.2013-0023

33. Siemens DR, Mackillop W, Peng P, et al. Process of care variables explaining the influence of surgical volumes in bladder cancer outcomes: a population-based study. J Urol 2013;189:e21-e22. http:// dx.doi.org/10.1016/i.juro.2013.02.1429

Correspondence: Dr. Christopher Booth, Division of Cancer Care and Epidemiology, Queen's University Cancer, Research Institute, 10 Stuart St., Kingston, ON, K7L 3N6; fax: 613-533-6794; booth@@kgh.kari.net 